\title{
PEMBELAJARAN PENELITIAN TINDAKAN KELAS DI PERGURUAN TINGGI ISLAM
}

\section{Mohamad Erihadiana}

ADPISI (Asosiasi Dosen Pendidikan Agama Islam)

Gedung PKM Lt. 2 UPI Jl. Dr. Setiabudi No. 229 Bandung.

E-mail: erihadiana@gmail.com

\begin{abstract}
ABSTRAK
Penelitian ini bermaksud mengembangkan sebuah 'model' pembelajaran Penelitian Tindakan Kelas yang dapat meningkatkan kemampuan bernalar (logis dan ilmiah) calon guru di salah satu perguruan tinggi Islam di Indonesia yaitu di Fakultas Tarbiyah dan Keguruan UIN Sunan Gunung Djati Bandung. Pendekatan yang digunakan dalam penelitian ini adalah Research and Development. Hasil eksperimen dan validasi membuktikan ada peningkatan hasil belajar dan perbedaan antara hasil eksperimen implementasi model yang digunakan dibandingkan dengan pembelajaran seperti biasa. Pelaksanaannya masih menghadapi beberapa kendala diantaranya; 1) Banyak dosen pengampu mata kuliah PTK yang belum memahami betul konsep PTK; 2) Dosen banyak yang mengajar dengan sistem asistensi, sehingga proses diskusi kurang berbobot karena asisten dosen mengalami kesulitan untuk berdiskusi secara baik; 3) Beberapa dosen jarang memberikan laporan observasi implementasi pembelajaran apalagi melakukan koreksi atas hasil belajar dan/atau tes; 4) Mahasiswa yang mengikuti perkuliahan PTK mayoritas belum pernah mengajar dan belum mengikuti Praktik Pengalaman Lapangan (PPL).
\end{abstract}

Kata Kunci: Pembelajaran, Penelitian Tindakan Kelas, Perguruan Tinggi Islam

\section{ABSTRACT}

This study intends to develop a learning model of classroom action research (CAR) that can improve the ability of reasoning (logical and scientific) of the prospective teachers in one of the Islamic universities in Indonesia, in Faculty of Tarbiyah and Teacher Training UIN Sunan Gunung Djati Bandung. The approach used in this study was a Research and Development. The result of the experiement and its validation prove there is an increase in learning outcomes and the difference between the result of of the implementation of experimental model compared to that of the implementation of conventional learning model. The implementation still faces several problems such as: 1) Many lecturers of CAR courses do not fully understand the concept of CAR; 2) lecturers who are belped by assistants causes the discussion process is less comprehensive since the assistants lack of knowledge about the topic discuss; 3) Some lecturers rarely gave the report about the implementation observed; 4) students who attend a course $C A R$ majority have never been tanght and have not followed the Teaching Practice (PPL).

Keywords: Learning, Classroom Action Research, Islamic Universities 


\section{PENDAHULUAN}

Undang-Undang RI Nomor 14 Tahun 2005 menyebutkan bahwa guru dan dosen wajib memiliki kualifikasi akademik, kompetensi, sertifikat pendidik, sehat jasmani dan rohani serta memiliki kemampuan untuk mewujudkan tujuan pendidikan nasional. Kualifikasi akademik yang dimaksud adalah tingkat pendidikan minimal yang harus dipenuhi oleh seorang pendidik yang dibuktikan dengan ijazah dan/atau sertifikat keahlian yang relevan dengan ketentuan perundang-undangan yang berlaku yakni harus memiliki kualifikasi pendidikan sarjana (S-1) atau D-4 dan memiliki sertifikat pendidik. Kompetensi yang harus dimiliki guru pada jenjang pendidikan dasar dan menengah serta pendidikan anak usia dini meliputi kompetensi; 1) pedagogik; 2) kepribadian; 3) profesional; dan 4) sosial (Peraturan Pemerintah Nomor 19 Tahun 2005 Tentang Standar Nasional Pendidikan, ayat 3). Sejumlah kompetensi yang disyaratkan oleh undang-undang tersebut mengandaikan bahwa guru harus bersikap inovatif dan profesional yakni menguasai pelbagai strategi baru yang lebih efektif dalam membelajarkan siswa.

Aspek-aspek yang berhubungan dengan kompetensi di atas di antaranya; 1) memiliki kepribadian yang matang namun senantiasa berkembang ke arah yang lebih baik; 2) kuat dalam penguasaan ilmu pengetahuan dan teknologi; 3) terampil dalam membangkitkan minat dan potensi peserta didik; 4) mengembangkan profesinya secara berkesinambungan; 5) mempunyai komitmen yang tinggi terhadap kemajuan siswa dan proses belajarnya; 6) bertanggungjawab dalam memantau hasil belajar siswa; 7) mampu berpikir sistematis dan dapat belajar dari pengalamannya; 8) merupakan bagian yang tak terpisahkan dari masyarakat pembelajar dalam lingkungannya (Nurzaman: 2007). Dari delapan aspek tersebut jika dicermati ternyata kemampuan berpikir sistematis merupakan kompetensi dasar bagi seorang guru yang berpotensi dapat memahami dan melaksanakan tugas profesionalnya. Mampu berpikir sistematis berarti secara otomatis mampu berpikir logis. Mampu berpikir logis memudahkan seseorang berpikir ilmiah. Tiga kemampuan berpikir saja, jika betul-betul sudah dikuasai oleh guru maka hampir dipastikan, delapan aspek di atas mampu dipenuhi oleh guru, termasuk hal-hal yang berhubungan dengan upaya memecahkan masalah pembelajaran di kelas. Dengan demikian, sejak menjadi mahasiswa keguruan/calon guru, kemampuan berpikir sistematis, terutama berpikir logis dan ilmiah harus dilatihkan kepada mereka dan dikuasai dengan baik oleh mereka. Salah satu mata kuliah yang memungkinkan dapat membekali mahasiswa calon guru keterampilan berpikir sistematis, logis dan ilmiah bahkan reflektif dan praksis adalah pemberian Mata Kuliah Penelitian Tindakan Kelas.

Mata Kuliah PTK dapat menjadi sebuah kajian sistematik mengenai sejumlah upaya perbaikan pelaksanaan pembelajaran yang dilakukan oleh guru dengan melakukan tindakan-tindakan tertentu berdasarkan analisis sistematis, logis dan reflektif atas hasil tindakan pembelajaran sebelumnya (Ebbutt dan Hopkins dalam Wiriatmadja, 2008: 12). Artinya, di dalam Mata Kuliah PTK 
terdapat sejumlah kemampuan dan aktivitas berpikir yang perlu diberikan kepada calon guru yaitu berpikir sistematis, analisis, praksis, reflektif, logis dan ilmiah. Dalam pandangan Suriasumantri seluruh aktivitas berpikir tersebut disebut dengan penalaran (Suriasumantri, 1998: 43). Jika calon guru sudah mampu bernalar dengan baik pada dasarnya ia telah siap berpikir, merasa, bersikap dan bertindak menjadi guru yang baik.

Fakultas Tarbiyah dan Keguruan UIN Sunan Gunung Djati Bandung sebagai Lembaga Penghasil Tenaga Pendidik dan Kependidikan (LPTK) juga menyajikan Mata Kuliah PTK namun dalam pelaksanaannya masih terjebak pada formalitas dan rutinitas saja. Penyebab utamanya adalah tidak semua dosen pengampu Mata Kuliah PTK memahami konsep inti PTK, termasuk muatan penalaran tadi. Beberapa kelas bahkan diajarkan dengan sistem asistensi sehingga dosen utama/senior/pembina jarang masuk kelas. Mahasiswa yang mengikuti perkuliahan PTK mayoritas belum melaksanakan Praktik Pengalaman Lapangan (PPL) sehingga mereka belum berpengalaman mengajar. Sarana prasarana yang ada seperti in-focus/LCD belum dimanfaatkan secara maksimal. Koleksi bukubuku PTK (terutama yang primer) di perpustakaan fakultas belum representatif.

Dengan memperhatikan kebutuhan dan permasalahan di atas maka perlu diteliti dan dikembangkan sebuah model pembelajaran PTK yang dapat meningkatkan kemampuan bernalar (logis dan ilmiah) calon guru. Proses perkuliahan PTK sedemikian rupa dirancang sehingga dapat berdampak terhadap peningkatan kemampuan berpikir logis dan ilmiah mahasiswa calon guru. Pendekatan yang digunakan dalam penelitian ini adalah penelitian dan pengembangan (Research and Development atau $R$ \& $D$ ) dengan sasaran mengembangkan dan menguji produk (Sukmadinata, 2007: 57). Langkahlangkah dalam penelitian ini terdiri atas tiga tahap yaitu: (1) studi pendahuluan; (2) pengembangan model; dan (3) uji model. Studi pendahuluan dilakukan dengan mengkaji teori serta mengamati model dan kegiatan yang ada. Pengembangan model dilakukan dengan mengembangkan produk atau model baru. Kegiatan pengembangan dilakukan melalui beberapa kali uji coba, dengan sampel terbatas dan sampel lebih luas. Uji model dilakukan dengan eksperimen. Subjek penelitian adalah mahasiswa Jurusan Pendidikan Agama Islam dan Pendidikan Guru Madrasah Ibtidaiyah (PGMI) semester 6 Tahun Akademik 2011/2012 yang mengikuti perkuliahan PTK. Tempat penelitian di Fakultas Tarbiyah dan Keguruan UIN Sunan Gunung Djati Bandung. Penetapan sampel dilakukan dengan purposif yaitu didasarkan pada adanya tujuan tertentu karena keterbatasan dana, waktu dan tenaga (Arinkunto, 1998: 127-128). Pemilihan lokasi uji coba terbatas dan luas didasarkan pada jumlah kelas dan rombongan belajar, serta kesiapan dosen yang menjadi mitra dalam penelitian ini. Uji coba terbatas dilakukan pada satu kelas yakni di Jurusan PAI dan uji coba lebih luas dilakukan pada tiga kelas yaitu satu kelas di Jurusan PAI dan dua kelas di Jurusan PGMI. 
Lokasi dan Subjek Penelitian

\begin{tabular}{|c|l|c|c|c|c|}
\hline No & Jurusan & Kelas & Jumlah & $\begin{array}{c}\text { Uji } \\
\text { Terbatas }\end{array}$ & $\begin{array}{c}\text { Uji Lebih } \\
\text { Luas }\end{array}$ \\
\hline 1. & PAI & D & 37 & V & V \\
\hline 2. & PAI & E & 39 & & V \\
\hline 3. & PGMI & A & 38 & & V \\
\hline 4. & PGMI & B & 37 & & V \\
\hline \multicolumn{2}{|l|}{ Jumlah } & & 151 & & \\
\hline
\end{tabular}

Teknik dan alat pengumpulan data menggunakan observasi, angket, tes dan skala sikap. Data dianalisis secara deskriptif-kualitatif dan kuantitatif dengan menggunakan statistik non-parametrik. Secara kualitatif dilakukan dengan: 1) mereduksi data; 2) menyajikan data; dan 3) mengambil kesimpulan dan verifikasi. Analisis kualitatif dilakukan untuk mendeskripsikan pelaksanaan pembelajaran. Analisis kuantitatif digunakan untuk menganalisis tingkat pencapaian tujuan penelitian yaitu kemampuan berpikir reflektif, logis dan ilmiah. Analisis data juga digunakan sebagai dasar penyusunan model akhir pembelajaran.

\section{PEMBAHASAN}

\section{Model-Model Pembelajaran}

Model diartikan sebagai kerangka konseptual yang digunakan sebagai pedoman dalam melakukan kegiatan. Model pembelajaran merupakan rancangan atau pola yang dijadikan pedoman dalam perencanaan program dan penyusunan pembelajaran agar tujuan pembelajaran yang ditentukan tercapai dengan baik (Sagala, 2006: 175). Dahlan (1990: 21) menyatakan bahwa model pembelajaran adalah suatu rencana atau pola yang digunakan untuk menyusun kurikulum, mengatur materi pembelajaran dan memberi petunjuk kepada pengajar ketika di kelas dalam setting pembelajaran ataupun setting lain yang dapat mendukung pembelajaran. Model pembelajaran yang baik setidaknya memiliki enam langkah yang harus ditempuh yaitu;

1. Membuat skenario dari model yang bersangkutan yang berisi strategi pembelajaran yang digunakan guru di dalam kelas. Skenario hendaknya menggambarkan proses pembelajaran dan semua kegiatan yang akan dilaksanakan di kelas secara konkret;

2. Membuat model pembelajaran yang meliputi tujuan, asumsi teoretik, prinsip dan konsep umum yang terkandung dalam model tersebut;

3. Menganalisis model mengajar yang terdiri atas: (a) langkah-langkah (syntax) model yang diuraikan dalam serangkaian kegiatan konkret di kelas; (b) sistem sosial yang dikembangkan yang menggambarkan peranan dan hubungan antara guru dengan murid dan norma yang mengikat mereka di kelas; (c) prinsip-prinsip mereaksi yaitu cara guru menghargai (to regard) dan merespons murid baik dengan memberikan 
nilai maupun hadiah atas hasil, perilaku dan pekerjaan siswa; (d) sistem penunjang atau sarana yang dapat membantu siswa belajar mandiri lengkap dengan sumber belajar lainnya;

4. Menerapkan model pembelajaran di dalam kelas;

5. Menyimpulkan dampak yang muncul dari hasil penerapan model yang terdiri atas dampak instruksional dan penyerta (nurturant);

6. merevisi dan mengembangkan model berdasarkan hasil evaluasi dan informasi yang diperoleh setelah model diterapkan dalam pembelajaran

(Dahlan, 1990: 21).

Joyce dan Weil (1992: 1) menyebutkan bahwa model pembelajaran adalah alat untuk membantu siswa dalam memperoleh informasi, ide, keterampilan, nilai, cara berpikir dan sarana mengekspresikan guru dalam mengajarkan cara murid belajar agar menjadi manusia pembelajar. Model pembelajaran yang bertolak dari konsep umum, kemudian dijabarkan dalam bentuk yang lebih rinci untuk menguji kebenaran konsep atau rumusan umum dinamakan model deduktif. Pembelajaran yang dimulai dari contoh-contoh konkret menuju generalisasi atau prinsip umum dinamakan model induktif. Sudjana (1993: 86102) mengatakan setidaknya ada empat model pembelajaran yaitu:

1. Model kegiatan belajar keterampilan, yaitu model pembelajaran yang berfokus pada pengalaman belajar di dalam dan melalui gerakangerakan yang dilakukan oleh peserta didik. Di dalam psikologi belajar dikemukakan bahwa gerak ini disebut dengan istilah motor learning, motor skills, psychomotor skills, skills dan skills performance. Gerak (motor) ialah kegiatan badani yang disebabkan oleh adanya tiga unsur yang tergabung dalam situasi kegiatan belajar yaitu gerak, stimulus dan respons. Ketiga unsur tersebut menumbuhkan pola gerak yang terkoordinasi pada diri siswa. Kegiatan belajar terjadi apabila peserta didik menerima stimulus kemudian merespons dengan menggunakan gerak. Penggunaan gerak dilakukan secara berulang-ulang dengan maksud menguatkan dan memantapkan gerak yang telah dilakukan serta menjadikan gerak itu sebagai pola gerak pada waktu menghadapi stimulus yang sama.

2. Model kegiatan belajar pengetahuan, yaitu model pembelajaran yang mendasari pembelajaran keterampilan. Keterampilan bisa berkembang apabila peserta didik telah memahami hubungan antar bagian dengan seluruh keterampilan yang dipelajari. Sebuah masalah dapat dipecahkan apabila konsep telah disusun dan diterapkan dalam mencari alternatif pemecahan masalah. Kegiatan belajar pengetahuan meliputi cognitive domain yang dikemukakan Bloom dan mencakup pemahaman, pengetahuan dan keterampilan berpikir. Pembelajaran yang termasuk ke dalam model pembelajaran pengetahuan adalah pembelajaran: (a) informasi; (b) konsep; dan (c) prinsip. 
3. Model kegiatan belajar sikap, yaitu pola tindakan yang ada pada diri siswa dalam merespons stimulus tertentu. Sikap merupakan kecenderungan perasaan dan perbuatan yang konsisten yang ada pada diri seseorang. Sikap berhubungan dengan minat (interest), nilai (values), penghargaan (appreciation), pendapat (opinions) dan purbasangka (prejudice). Perbedaannya terletak pada intensitas dan keragaman motivasi di dalam diri peserta didik serta tingkatan perasaannya dalam merespons atau bertindak terhadap stimulus. Sikap, minat, nilai dan penghargaan termasuk ke dalam ranah afektif. Sikap merupakan 'kekuatan terdalam' (inner power) siswa untuk mengembangkan diri dan meningkatkan kualitas kehidupannya.

4. Model belajar pemecahan masalah, yaitu model pembelajaran yang dapat memenuhi dua kepentingan; pertama pemecahan masalah yang mengarah kepada situasi; kedua, keluar dari situasi (masalah) sekarang dan masuk kepada situasi yang diinginkan.

Model pembelajaran pada dasarnya berparalel dengan lesson plan atau rencana pengajaran. Kemampuan membuat lesson plan dalam berbagai bentuk didasari oleh basic teaching model atau model dasar pembelajaran. Oleh karena itu, berbagai model pembelajaran sebenarnya dikembangkan dari model pembelajaran dasar. Menurut Tafsir (2004: 44-45), langkah-langkah model dasar dari Glaser dapat dijadikan acuan untuk mengembangkan model pembelajaran.

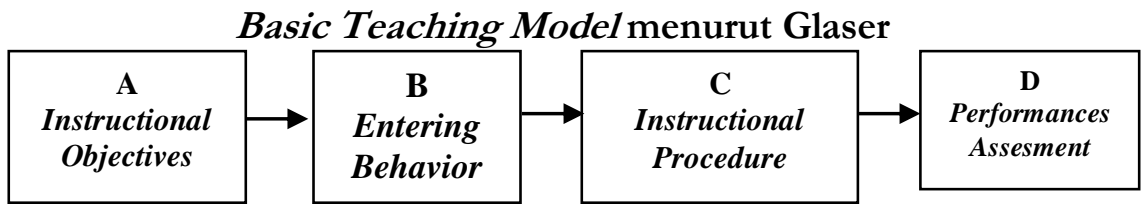

Menurut Glaser langkah terpenting dalam membuat lesson plan adalah merumuskan tujuan pembelajaran (instructional objectives). Tujuan pembelajaran tidak boleh menyimpang dari tujuan pendidikan yang hendak dicapai. Tujuan pembelajaran yang dimaksud adalah pola tingkah laku khusus yang diharapkan dimiliki dan dikuasai murid setelah pembelajaran selesai. Langkah kedua adalah kesiapan murid sebelum pembelajaran dimulai atau disebut dengan entering behavior. Dalam entering behavior bukan saja dituntut mengetahui kesiapan belajar murid tetapi juga upaya untuk memotivasi siswa dalam mengikuti proses pembelajaran harus jelas. Langkah ketiga adalah menentukan prosedur pembelajaran (intructional procedure). Langkah ini adalah langkah utama dalam kegiatan pembelajaran. Langkah terakhir adalah evaluasi. Kegiatan ini dilakukan untuk mengetahui ketercapaian tujuan pembelajaran sekaligus menjadi masukan bagi penyempurnaan model pembelajaran.

Secara teologis, perintah untuk mengajar dengan model, cara dan isi pembelajaran yang baik diperintahkan al Quran sebagai mana tercantun dalam surat al-Nahl (16) ayat 125, yaitu; "Serulah (manusia) kepada jalan Tuhan-mu 
dengan hikmah dan pelajaran yang baik...." (Yasa, 2013: 3). Inti dari model pembelajaran adalah menyusun perencanaan, pola dan program sebaik mungkin. Allah SW'T menegaskan betapa sebuah rencana yang baik dapat membangun rasa percaya diri seseorang ketika bertindak, "Dan Aku memberi tangguh kepada mereka. Sesungguhnya rencana-Ku amat teguh" (Q.S. Al A'rāf [7]: 183 dalam Digital Al Quran Versi 3.2 juz 8).

\section{Penelitian Tindakan Kelas}

Penelitian tindakan kelas (PTK) merupakan suatu penelitian yang bersifat analitis, sistematis dan reflektif dilakukan oleh guru untuk meningkatkan kemampuan rasional dari tindakan yang dilakukan guru dalam memperbaiki atau meningkatkan praktik pembelajaran di kelasnya. PTK pertama kali diperkenalkan oleh ahli psikologi sosial Amerika yang bernama Kurt Levin pada tahun 1946. Inti gagasan Levin ini selanjutnya dikembangkan oleh ahli pendidikan seperti Stephen Kemmis, Robin Mc Tanggart, John Elliot, Dave Ebbutt McNiff dan Stepen M. Corey (Supardi, 2010: 101-102). Di Indonesia, PTK baru dikenal pada akhir dekade 1980-an. Oleh karena itu jenis penelitian ini masih dianggap baru dan keberadaannya sebagai salah satu jenis penelitian pun masih sering menjadi perdebatan ketika dihubungkan dengan bobot keilmiahannya.

Menurut Stephen Kemmis (1983), PTK adalah suatu bentuk kegiatan penelaahan atau inkuiri melalui refleksi diri yang dilakukan oleh peserta kegiatan pendidikan tertentu dalam situasi sosial (termasuk pendidikan) untuk memperbaiki rasionalitas dan kebenaran dari (a) pelbagai praktik sosial atau pendidikan yang mereka lakukan sendiri, (b) pemahaman mereka terhadap praktik-praktik tersebut, dan (c) situasi di tempat praktik itu dilaksanakan (David Hopkins, 1993: 44).

Prinsip-prinsip pelaksanaan PTK antara lain tidak mengganggu komitmen guru sebagai pengajar, pelaksanaan PTK tidak menuntut waktu yang berlebihan dari guru sehingga dapat mengganggu proses pembelajaran. Metodologi yang digunakan pun harus cukup reliabel sehingga dapat dipertanggungjawabkan. Masalah mendasar dari PTK adalah banyaknya guru yang merasa risau bahwa dalam memperbaiki proses belajar-mengajar harus menempuh prosedur etika penelitian. Agar memudahkan guru, Lewin merumuskan empat tahapan dalam pelaksanaan PTK (Kemmis dan Mc Taggar, 1992) yaitu Planning (Rencana), Action (Tindakan), Observation (Pengamatan), dan Reflection (Refleksi). Rencana berisi analisis masalah dan strategi perencanaan. Tindakan berisi implementasi strategi yang direncanakan. Pengamatan berisi deskripsi kegiatan lengkap dengan penggunaan teknik tertentu. Refleksi merupakan tindakan mengevaluasi proses dan hasil sebagai masukan bagi siklus selanjutnya. Dengan demikian secara umum PTK adalah suatu tindakan yang diambil oleh guru atau koleganya untuk meningkatkan pengajaran atau menguji sejumlah teori dengan praktik. Secara sosiologis PTK dapat dimaknai sebagai 
upaya sistematik dan kritis dengan melibatkan/melihat dasar filosofis, penggunaan bukti-bukti dan rujukan terhadap teori. Tetapi tidak ada alasan bahwa pekerjaan itu tidak akan berakhir dengan teori. Justru penelitian tindakan kelas menolong pengajar untuk berteori, yaitu berpikir lebih sistematik, kritis, dan cerdas mengenai praktik mengajar. Menurut Kemmis dan Taggart, penelitian tindakan adalah studi yang dilakukan untuk memperbaiki diri sendiri, pengalaman kerja sendiri, tetapi dilaksanakan secara sistematis, terencana dan dengan sikap mawas diri. Menurut Hopkins, PTK adalah suatu bentuk kajian yang bersifat reflektif oleh pelaku tindakan, yang dilakukan untuk meningkatkan kemantapan rasional dari tindakan-tindakan mereka dalam melaksanakan tugas, memperdalam pemahanan terhadap kondisi dan tempat praktik pembelajaran dilakukan.

Dalam PTK, guru berperan ganda yaitu sebagai peneliti sekaligus sebagai pelaksana pembelajaran. Karena itu PTK disebut sebagai suatu upaya dalam rangka menjelaskan berbagai aspek secara berhubungan antara materi, pembelajar dan pengajar dengan isu totalitas dan logika internal dari tugas guru sebagai makhluk sosial dalam mengonstruksi pengetahuan. PTK adalah suatu penelitian yang dilakukan guru/dosen untuk memperbaiki mutu dan proses pembelajaran yang menjadi tanggung jawabnya. Substansi PTK meliputi konsepkonsep; (a) praktik. Bagaimanapun juga hasil dan pemahaman diperoleh tidak hanya berdasarkan teori tentang kondisi lapangan tetapi mengarahkan pada perbaikan selama/setelah proses penelitian yang hanya bisa ditempuh dengan tindakan nyata/amal; (b) partisipasi aktif dan kolaboratif. Peneliti tidak menempatkan diri sebagai orang luar tetapi sebagai kelompok kerja yang peduli dengan masalah praktis dan perbaikan aktual; (c) emansipatoris, yaitu pendekatan ini tidak hierarchical tetapi semua orang memiliki kepedulian yang kedudukannya sama yakni sebagai partisipan; (d) interpretatif. Dalam PTK validitas penelitian diperoleh melalui metode tertentu, solusi berdasarkan pada wawasan dan interpretasi seseorang yang terlibat dalam penelitian, bukan menjawab benar atau salah; dan (e) kritis. PTK tidak hanya mencari perbaikan tetapi menjadikan yang diteliti sebagai agen pembaharu.

Secara teologis, konsep PTK bersesuain dengan ajaran Islam terutama dengan konsep 'amal yang berarti tindakan/aksi/perbuatan. Hal ini isyaratkan oleh Az-Zarnuji dalam pembukaan kitab Ta'lim al Muta'alim yaitu alhamdulillâh alladそ̂̂ fadldlala banî âdam bi al-'ilmi wa al-'amal 'alâ jamî'i al-'âlam...bahwa Allah SWT telah meninggikan umat manusia di atas alam yang luas ini dengan dua perkara yaitu ilmu dan amal/tindakannya (Az-Zarnuji, 11:2). Bahkan Allah berfirman, "Dia menguji kamu, siapa di antara kamu yang lebib baik (perbuatan) amalnya" (Q.S. al Mulk [67]: 2 dalam Digital Al Quran Versi 3.2. juz 29). Dengan demikian, hal yang terpenting dari tugas seorang guru itu bukan hanya mendakwahkan, menginformasikan, mewacanakan dan berteori mengenai model/metode/ teknik/strategi/media mengajar yang baik tetapi justru guru harus mampu 
mewujudkan/mempraktikkan dengan tindakan nyata cara-cara mengajar tersebut bahkan mampu mengatasi kesulitan anak dalam belajar.

\section{Berpikir Logis dan Ilmiah}

Berpikir yang didasarkan kepada penalaran adalah proses berpikir yang menghasilkan pengetahuan yang benar. Agar pengetahuan yang dihasilkan penalaran itu mempunyai dasar kebenaran maka proses berpikir itu harus dilakukan dengan cara tertentu yang menghasilkan kesimpulan yang valid atau sahih. Cara penarikan kesimpulan yang sahih ini disebut dengan logika. Logika adalah dasar bagi pengetahuan ilmiah yang bersumber kepada dua hal yaitu: (a) rasio; dan (b) fakta. Filsafat yang menganggap bahwa sumber kebenaran adalah rasio atau akal dikenal dengan aliran rasionalisme. Adapun aliran yang menyatakan bahwa fakta yang tertangkap melalui pengalaman manusialah sumber kebenaran, disebut dengan empirisme. Di dalam kajian filsafat ilmu, hal yang diutamakan adalah logika atau penalaran ilmiah, karena mutu keilmuan diukur dengan kekuatan logika. Logika ilmiah pada dasarnya adalah gabungan antara logika deduktif dengan induktif. Logika deduktif berhubungan dengan rasionalisme dan logika induktif berkaitan dengan empirisme. Logika adalah cara berpikir yang diawali dengan pernyataan yang bersifat umum kemudian diperoleh kesimpulan yang bersifat khusus melalui pola yang disebut silogisme. Silogisme disusun berdasarkan dua pernyataan yang disebut premis mayor dan premis minor dan satu pernyataan yang disebut kesimpulan. Sedangkan logika induktif adalah cara berpikir dengan menarik kesimpulan umum berdasarkan pernyataan-pernyataan/kasus yang khusus (Suriasumantri, 1998: 45-49). Berarti, berpikir logis dapat diartikan sebagai suatu kegiatan untuk memahami sesuatu dan berusaha mencari jalan keluar dari permasalahan yang sedang dihadapi dengan lebih banyak melibatkan kerja otak.

Berpikir logis dapat dikategorikan sebagai berpikir deduktif karena ia merupakan proses berpikir yang bertolak pada proposisi yang sudah ada, menuju proposisi baru yang berbentuk suatu kesimpulan, yang mana kesimpulan tersebut diambil dari dua pernyataan, dan pernyataan pertama merupakan pernyataan umum. Berpikir pun dapat dapat ditempuh secara induktif apabila menarik kesimpulan umum dari berbagai kasus yang bersifat individual. Berpikir logis dapat berupa berpikir evaluatif yaitu berpikir kritis, menilai baik-buruk dan tepat atau tidaknya suatu gagasan. Berawal dari berpikir kemudian muncul ide dan konsep. Dua jalan berpikir ini disebut dengan penalaran. Berarti penalaran adalah proses berpikir yang menghasilkan pengetahuan yang benar baik secara logis maupun empiris. Penalaran inilah yang mendasari seseorang mampu berpikir ilmiah. Setidaknya ada empat ciri berpikir ilmiah yaitu; objektif; rasional; terbuka; dan benar. Berpikir ilmiah adalah berpikir logis-empiris dan benar. Dari berpikir ilmiah lahir metode ilmiah yang isinya logico-bypotetico-verificatif artinya, sesuatu yang benar itu harus logis, didukung oleh fakta empiris dan harus dapat dibuktikan kebenarannya. 


\section{Model Pembelajaran PTK Berbasis Berpikir Logis-Ilmiah}

Hasil penelitian berupa deskripsi dan interpretasi dikelompokan berdasarkan tahapan dalam penelitian dan pengembangan yaitu: 1) hasil studi pendahuluan, 2) perencanaan dan persiapan format pengembangan model pembelajaran, serta 3) uji coba model pembelajaran. Hasilnya kemudian dirangkum menjadi sebuah model pembelajaran yang ditujukan untuk meningkatkan keterampilan berpikir logis dan ilmiah bagi mahasiswa Fakultas Tarbiyah dan Keguruan (FTK) UIN Sunan Gunung Djati Bandung terutama bagi mereka yang mengikuti mata kuliah PTK.

Hasil studi pendahuluan terdiri dari dua bagian yaitu: 1) hasil survei awal sebagai studi lapangan/empiris, dan 2) desain model hipotetik pembelajaran sebagai hasil studi literatur yang dikaitkan dengan hasil survei awal. Survei awal bertujuan untuk mendeskripsikan kondisi pembelajaran termasuk faktor pendukung dan penghambat mahasiswa Fakultas Tarbiyah Dan Keguruan khususnya di Jurusan PAI (Pendidikan Agama Islam) dan PGMI (Pendidikan Guru Madrasah Ibtidaiyah) yang menjadi lokasi dan sampel dalam penelitian ini. Kegiatan ini dilakukan secara efektif selama bulan Februari 2012.

Berdasarkan hasil observasi dan wawancara kepada dosen dan mahasiswa FTK UIN Bandung yang mengikuti perkuliahan PTK diperoleh gambaran:

1. Mayoritas dosen berpendapat bahwa pembelajaran dan keterampilan berpikir logis dan ilmiah bermanfaat dan dibutuhkan oleh mahasiswa.

2. Mahasiswa berpendapat bahwa pembelajaran mata kuliah PTK di FTK bermanfaat, namun lebih banyak bersifat personal sebab tidak semua dosen membahas hasil ujian atau tugas yang diberikan kepada mahasiswa.

3. Berdasarkan kondisi pembelajaran yang membutuhkan praktik dan evaluasi, maka ditetapkan kelas uji coba terbatas dan luas agar diperoleh suatu pengembangan model pembelajaran yang dapat meningkatkan keterampilan berpikir logis dan ilmiah bagi mahasiswa di Jurusan PAI dan PGMI.

Tahapan yang dilakukan dalam pengembangan model pembelajaran terdiri atas penyusunan draft model, uji coba tahap I, uji coba tahap II dan menyusun model akhir pembelajaran. Langkah-langkah kegiatan yang dilakukan dalam penyusunan draft model adalah:

1. Merancang model hipotetik pembelajaran Mata Kuliah Penelitian Tindakan Kelas untuk meningkatkan keterampilan berpikir logis dan ilmiah bagi mahasiswa Fakultas Tarbiyah dan Keguruan UIN Sunan Gunung Djati Bandung yang dikembangkan berdasarkan kajian teoretik, kondisi objektif lapangan, kajian hasil penelitian terdahulu yang relevan berdasarkan ketentuan formal pelaksanaan pembelajaran PAI di SMA.

2. Menganalisis kesenjangan (hal yang tidak relevan) antara pelaksanaan pembelajaran Mata Kuliah Penelitian Tindakan Kelas dengan tujuan 
penelitian yaitu untuk meningkatkan keterampilan berpikir logis dan ilmiah mahasiswa Fakultas Tarbiyah dan Keguruan UIN Sunan Gunung Djati Bandung.

3. Membuat lesson plan (Satuan Acara Perkuliahan/SAP) Mata Kuliah Penelitian Tindakan Kelas yang dirancang khusus untuk meningkatkan keterampilan berpikir logis dan ilmiah mahasiswa Fakultas Tarbiyah dan Keguruan UIN Sunan Gunung Djati Bandung. yaitu:

Ada beberapa tahapan kegiatan yang dilakukan pada uji coba tahap I ini

1. Melaksanakan uji coba terbatas dalam kelas yang dilakukan oleh dosen Mata Kuliah PTK pada satu kelas di Jurusan PAI.

2. Melakukan diskusi tentang hasil uji coba untuk mengetahui kendalakendala yang menyebabkan terhambatnya pengembangan model Mata Kuliah Penelitian Tindakan Kelas untuk meningkatkan keterampilan berpikir logis dan ilmiah mahasiswa Fakultas Tarbiyah dan Keguruan UIN Sunan Gunung Djati Bandung.

3. Merumuskan upaya-upaya pemecahan terhadap masalah yang dihadapi bersama (dosen dan mahasiswa) dalam rangka penyempurnaan model.

4. Mendekripsikan hasil pelaksanaan uji coba model.

Ada beberapa tahapan kegiatan yang dilakukan pada uji coba tahap II ini yaitu:

1. Melakukan uji coba model untuk seluruh kelas Mata Kuliah PTK di Jurusan PAI dan PGMI Fakultas tarbiyah dan Keguruan UIN Sunan Gunung Djati Bandung.

2. Merumuskan model pembelajaran Mata Kuliah Penelitian Tindakan kelas hipotetik yang telah direvisi.

Setelah melakukan beberapa kali uji coba maka diperoleh model akhir pembelajaran Mata Kuliah Penelitian Tindakan Kelas yang dirancang khusus untuk meningkatkan keterampilan berpikir logis dan ilmiah mahasiswa Fakultas Tarbiyah dan Keguruan UIN Sunan Gunung Djati Bandung. Model pembelajaran tersebut sedemikian rupa sudah dianggap mapan dan stabil dengan indikasi bahwa sejumlah faktor pendukung berkembang ke arah positif dan beberapa faktor penghambat dapat diminimalisasi. Model akhir pembelajaran Mata Kuliah Penelitian Tindakan Kelas untuk meningkatkan keterampilan berpikir logis dan ilmiah mahasiswa Fakultas Tarbiyah dan Keguruan UIN Sunan Gunung Djati Bandung tersebut mencakup pengembangan Rencana Pembelajaran dan kegiatan Pembelajaran.

Hasil pengembangan model pembelajaran melalui uji coba lebih luas yang dilakukan di Jurusan PAI dan PGMI Fakultas Tarbiyah dan Keguruan UIN Sunan Gunung Djati Bandung bertujuan untuk mengetahui tingkat keefektifan model pembelajaran yang dikembangkan ketika suatu saat diimplementasikan di tempat lain dengan kondisi yang berbeda dengan 
yang di lokasi penelitian. Model tersebut kemudian diperbaiki dan disempurnakan berdasarkan masukan yang ada dalam rangka penyempuranaan model sehingga siap divalidasi melalui eksperimen.

Temuan hasil uji coba yang lebih luas dilakukan melalui 4 putaran pembelajaran yang dirangkum sebagai berikut;

1. Desain model sejak penyusunan draft awal sampai model akhir secara prinsip tidak mengalami banyak perubahan.

2. Lembar observasi dan hasil tes serta angket digunakan sebagai panduan dalam pengimplementasian model.

3. Mahasiswa dilatih untuk mengekspresikan kemampuan berpikir secara logis dan ilmiah dalam proses perkuliahan.

4. Pembelajaran lebih efektif berbasiskan masalah pembelajaran yang akan dihadapi di kelas.

5. Instrumen kemampuan berfikir dan sikap ilmiah jika dilakukan dengan efektif maka akan dapat meningkatkan keterampilan berpikir logis dan ilmiah mahasiswa.

6. Model pembelajaran masih harus terus divalidasi melalui uji coba yang lebih luas lagi ke beberapa jurusan di Fakultas Tarbiyah dan Keguruan UIN Sunan Gunung Djati Bandung.

Validasi model pembelajaran dilakukan dengan mengimplementasikan pembelajaran melalui kegiatan eksperimen yakni menggunakan metode Eksperimen Semu (Quasi Experimenta). Desain eksperimen yang digunakan adalah Time-Series Design. Dalam desain ini tidak digunakan kelompok kontrol, sehingga hanya menggunakan satu kelompok yaitu kelompok eksperimen. Model pembelajaran yang diimplementasikan kemudian dibandingkan dengan model pembelajaran yang biasa dilakukan. Hasil eksperimen, menunjukkan bahwa implementasi model pembelajaran dapat dilakukan melalui tiga putaran pembelajaran. Putaran 1 penekanannya pada tahap mahasiswa melakukan latihan menemukan kebenaran; Putaran 2, tahap berpikir logis; Putaran ke 3 tahap analisis. Hasil validasi membuktikan ada peningkatan hasil belajar dan perbedaan yang signifikan (lebih besar) antara hasil eksperimen mengenai implementasi model perkuliahan PTK yang didesain khusus untuk meningkatkan kemampuan berpikir logis dan ilmiah dibandingkan dengan menggunakan model pembelajaran PTK pada umumnya. Nilai rata-rata hasil belajar mahasiswa berdasarkan hasil eksperimen pada mata kuliah Penelitian Tindakan Kelas tersebut disajikan dalam bentuk tabel berikut

Hasil Belajar Mahasiswa

\begin{tabular}{|c|c|c|c|c|c|c|c|c|}
\hline \multirow{2}{*}{ No } & \multirow{2}{*}{ Kelas } & \multirow{2}{*}{$\mathbf{N}$} & \multicolumn{2}{|c|}{ Rata-Rata } & \multirow{2}{*}{ Md } & $\begin{array}{c}\text { Nilai } \\
\text { t Hitung }\end{array}$ & df & \multirow{2}{*}{ t- table } \\
\cline { 4 - 5 } & & Awal & Akhir & & 4,72 & 39 & 2,02 \\
\hline 1 & $\mathrm{X}-1$ & 37 & 59,95 & 65,16 & 5,2 & 6,55 & 37 & 2,02 \\
\hline 2 & $\mathrm{X}-2$ & 38 & 58,95 & 67,89 & 8,96 & 7,612 & 37 & 2,02 \\
\hline 3 & $\mathrm{X}-3$ & 39 & 61,2 & 68,8 & 7,67 & 7,71 & 37 & 2,02 \\
\hline 4 & $\mathrm{X}-4$ & 37 & 58,7 & 67,2 & 8,6 & 7,6 \\
\hline
\end{tabular}


Berikut adalah model akhir pembelajaran Mata Kuliah Penelitian Tindakan Kelas di Fakultas Tarbiyah dan Keguruan UIN Sunan Gunung Djati Bandung;

\section{Desain Pembelajaran}

1. Tujuan: meningkatkan keterampilan berpikir Logis dan Ilmiah mahasiswa Fakultas Tarbiyah dan Keguruan UIN Sunan Gunung Djati Bandung.

2. Materi: sesuai dengan pokok-pokok materi pada silabus (konsep dasar/teori PTK dan penyusunan proposal PTK), Sumber: buku PTK, pedoman proposal PTK/skripsi, pustaka yang relevan dengan masalah.

3. Prosedur pembelajaran: tahap persiapan, menemukan kebenaran, berpikir logis, analisis ilmiah dan pemantapan.

4. Evaluasi: evaluasi proses pembelajaran, evaluasi hasil belajar, serta pengukuran kemampuan berpikir logis dan ilmiah.

\section{Implementasi Pembelajaran}

1. Tahap persiapan: memberikan motivasi agar mahasiswa berani mengemukakan pendapat, menjelaskan tujuan perkuliahan dan materi perkuliahan, apersepsi dan membahas tugas sebelumnya.

2. Tahap latihan penemuan kriteria kebenaran: menggunakan berbagai teknik (metode/media/contoh) agar mahasiswa memahami konsep kriteria kebenaran.

3. Tahap berpikir logis: mengaitkan materi yang dipelajari dengan konsep logika deduktif-induktif, sharing dan diskusi permasalahan mengajar dan melalui refleksi diri setiap mahasiswa mengemukakan masalah yang akan diteliti dengan PTK.

4. Tahap berpikir ilmiah: mendiskusikan pemecahan masalah dengan kerangka berpikir ilmiah: perumusan masalah, alternatif pemecahan masalah serta menarik kesimpulan.

5. Tahap pemantapan: merangkum materi yang dipelajari, melakukan refleksi diri, mengambil manfaat/hikmah, mengerjakan tugas dan soal tes dan membiasakan berpikir sistematis dan kritis.

\section{Evaluasi dan Tindak Lanjut Pembelajaran}

1. Evaluasi: proses pembelajaran dan hasil belajar serta pengukuran keterampilan berpikir logis dan ilmiah.

2. Tindak lanjut pembelajaran untuk perbaikan pembelajaran selanjutnya.

Pelaksanaan pembelajaran PTK di FTK UIN Sunan Gunung Djati Bandung masih menghadapi beberapa kendala karena; 1) Mata Kuliah PTK adalah mata kuliah yang relatif baru; 2) praktik untuk pemecahan masalah pembelajaran masih mengalami kesulitan karena miskinnya aktivitas praktis berakibat pada sulitnya mahasiswa berlatih mengekspresikan kemampuan berpikir melalui perkuliahan PTK; 3) Dosen pengampu Mata Kuliah PTK belum semua memahami konsep PTK, sehingga menghambat perencanaan dan pengimplementasian model pembelajaran, terutama dalam membuat desain (SAP) secara rinci dan tertulis. Beberapa dosen juga jarang memberikan laporan observasi implementasi pembelajaran apalagi melakukan koreksi hasil belajar dan tes esei berpikir logis dan ilmiah; 4) Dosen yang telah 
berpengalaman melakukan dan membimbing mahasiswa dalam menyusun skripsi dengan PTK sangat membantu peneliti maupun mahasiswa dalam mengimplementasikan model pembelajaran yang dilakukan secara siklikal dan kolaboratif, akan tetapi ada dosen yang memiliki persepsi dan cara serta gaya mengajar yang kadang agak sedikit sulit menerapkan secara konsisten tahapan model pembelajaran yang direncanakan; 5) Dosen Mata Kuliah PTK banyak yang mengajar dengan sistem asistensi, sehingga proses diskusi secara kolaborasi kurang mendapat banyak masukan dan pandangan karena dosen dengan asisten mengalami kesulitan untuk bertemu/berdiskusi secara lengkap, sehingga masukan dilakukan secara individual kemudian dirangkum oleh peneliti dalam penyusunan desain/SAP putaran selanjutnya, dan didiskusikan secara singkat sebelum implementasi putaran pembelajaran selanjutnya; 6) Mahasiswa yang mayoritas belum pernah mengajar dan belum mendapatkan Praktik Pengalaman Lapangan (PPL) menjadi faktor penghambat dalam Mata Kuliah PTK. Idealnya PTK adalah penelitian yang dilakukan oleh guru bukan oleh mahasiswa calon guru; 7) Sarana dan prasarana, walaupun Fakultas Tarbiyah dan Keguruan UIN Sunan Gunung Djati sudah memiliki memiliki in-focus di setiap ruangan kuliah, tetapi dosen dan mahasiswa terkadang belum memanfaatkannya secara maksimal. Perpustakaan di Fakultas Tarbiyah dan Keguruan UIN Sunan Gunung Djati Bandung sebenarnya sudah representatif, namun dalam kenyataannya koleksi buku perpustakaan dan karya ilmiah PTK belum mencukupi; 8) Evaluasi proses pembelajaran tidak dapat dilakukan peneliti secara optimal karena waktu perkuliahan yang hampir bersamaan. Namun dengan bantuan dan kerjasama dari dosen PTK, observasi proses pembelajaran dapat terlaksana dan cukup terwakili untuk dijadikan masukan pembelajaran selanjutnya. Evaluasi hasil belajar dalam bentuk pertanyaan maupun tugas yang relevan dengan tujuan dan pokok bahasan setiap putaran disusun oleh bersama, hasilnya dijadikan masukan bagi perbaikan putaran pembelajaran selanjutnya. Pengukuran kemampuan berpikir logis dan ilmiah mengalami hambatan saat menjawab dan mengumpulkan hasil tes esei berpikir logis dan ilmiah sebab tidak semua mahasiswa mengerjakan tugas dan mengumpulkan tepat waktu. Demikian juga ketika mengoreksi hasil, walau sudah ada kriteria tetapi dosen mata kuliah sebagai korektor kedua kadang-kadang mempunyai persepsi berbeda, dan tidak cukup waktu untuk melaksanakan inter-rater reliability. Pengumpulan dan analisis data hasil skala kemampuan berpikir logis dan ilmiah tidak terlalu banyak mengalami kendala karena dikerjakan di kelas dan langsung dikumpulkan kemudian diolah dan dianalisis.

\section{SIMPULAN}

Model pembelajaran PTK di FTK UIN Sunan Gunung Djati Bandung dikembangkan melalui tiga langkah penelitian dan pengembangan yaitu; studi pendahuluan, perencanaan dan pengembangan. Validasi terhadap Mata Kuliah 
Penelitian Tindakan Kelas didasarkan pada pendekatan pembelajaran untuk memperoleh pengetahuan yang didapatkan melalui metode ilmiah sebagai penggabungan dari metode deduktif dan induktif. Model desain pembelajaran PTK untuk tujuan meningkatkan kemampuan keterampilan berpikir logis dan ilmiah dengan prosedur pembelajaran yaitu; (a) persiapan yang meliputi kegiatan memberi motivasi agar mahasiswa berani mengemukakan pendapat; (b) menjelaskan tujuan perkuliahan dan materi perkuliahan; (c) apersepsi; dan (d) membahas tugas sebelumnya. Tahap latihan penemuan kriteria kebenaran menggunakan bebagai teknik (metode/media/contoh) agar mahasiswa memahami konsep kriteria kebenaran. Tahap berpikir logis berupaya mengaitkan materi yang dipelajari dengan konsep logika deduktif-induktif. Hal ini dilakukan melalui sharing dan diskusi tentang pelbagai permasalahan mengajar dan melalui refleksi diri setiap mahasiswa saat mengemukakan masalah yang akan diteliti dengan PTK. Tahap berpikir ilmiah meliputi kegiatan mendiskusikan pemecahan masalah dengan kerangka berpikir ilmiah (perumusan masalah, pengajuan alternatif pemecahan masalah, serta menarik kesimpulan). Tahap pemantapan meliputi kegiatan merangkum materi yang dipelajari dan melakukan refleksi diri. Hasil belajar mahasiswa dalam menguasai materi yang dipelajari pada setiap pertemuan serta pengukuran keterampilan berpikirnya dilakukan melalui tes kemampun berpikir dan skala sikap yang diberikan melalui pre-test dan post-test. Implementasi model pembelajaran dilakukan secara siklikal melalui beberapa putaran pembelajaran. Semuanya difokuskan pada prosedur pembelajaran yang terdiri atas: tahap persiapan yaitu memberikan motivasi agar mahasiswa berani mengemukakan pendapat, menjelaskan tujuan perkuliahan dan materi perkuliahan, apersepsi dan membahas tugas sebelumnya. Tahap latihan penemuan kriteria kebenaran meliputi kegiatan penggunaan bebagai teknik (metode/media/contoh) agar mahasiswa memahami konsep kriteria kebenaran. Tahap berpikir logis meliputi kegiatan mengaitkan materi yang dipelajari dengan konsep logika deduktifinduktif, sharing dan diskusi permasalahan mengajar melalui refleksi diri dari setiap mahasiswa saat mengemukakan masalah yang akan diteliti dengan PTK. Tahap berpikir ilmiah meliputi kegiatan mendiskusikan pemecahan masalah dengan kerangka berpikir ilmiah (perumusan masalah, alternatif pemecahan masalah, serta menarik kesimpulan). Tahap pemantapan meliputi kegiatan merangkum materi yang dipelajari, mengerjakan tugas dan soal tes dan membiasakan diri berpikir sistematis dan kritis. Evaluasi meliputi kegiatan penilaian proses pebelajaran, hasil belajar dan keterampilan berpikir logis dan ilmiah. Evaluasi proses pembelajaran dideskripsikan berdasarkan hasil observasi dan didiskusikan secara kolaboratif antara peneliti dengan dosen yang bersangkutan, hasilnya digunakan sebagai masukan bagi perbaikan pembelajaran selanjutnya. Evaluasi hasil belajar dilakukan pada setiap putaran pembelajaran untuk mengetahui pencapaian tujuan pembelajaran. Pengukuran keterampilan berpikir dilakukan dengan mengerjakan tes esei dan 
angket kemampuan berpikir logis dan ilmiah. Tindak lanjut pembelajaran dilakukan berdasarkan hasil evaluasi proses pembelajaran dan evaluasi hasil belajar untuk perbaikan selanjutnya.

\section{DAFTAR PUSTAKA}

Arikunto, Suharsimi. 1998. Prosedur Penelitian Suatu Pengantar. Jakarta: Rineka Cipta.

Az-Zarnuji, Syaikh. Tt. Ta'lim al Muta'allim. Surabaya: Harasma.

Dahlan, M. Djawad (Penyunting). 1990. Model-Model Mengajar. Bandung: Dipenogoro.

Digital Al Quran. Versi 3.2.

Hopkins, David. 1993. A Teacher Guide to Classroom Research. Philadelpia: Open University Press.

Joyce, Bruce and Marsha Weil. 1992. Models of Teaching. Boston: Allyn and Bacon.

Kemmis, Stephen and Robin Mc Taggart. 1989. The Action Research Planner. Victoria: Deakin University.

Nurzaman, Dede. 2007. Inovasi Pendidikan Agama Islam dalam Merespon Dibelakukannya KTSP. Makalah. Tidak Diterbitkan.

Peraturan Pemerintah Nomor 19 Tahun 2005 Tentang Standar Nasional Pendidikan.

Sagala, Syaiful. 2006. Konsep dan Makna Pembelajaran. Bandung: Alfabeta.

Sudjana, H. D. 1993. Strategi Pembelajaran dalam Pendidikan Luar Sekolah. Bandung: Nusantara Press.

Sukmadinata, Syaodih, Nana. 2007. Metode Penelitian Pendidikan. Bandung: PPs UPI dan Rosdakarya.

Supardi. 2010. Penelitian Tindakan Kelas (Classroom Action Research) Beserta Sistematika Proposal dan Laporannya. Dalam Arikunto dkk. 2010. Penelitian Tindakan Kelas. Jakarta: Bumi Aksara.

Suriasumantri, Jujun. 1998. Filsafat Ilmu. Sebuah Pengantar Populer. Jakarta: Pustaka Sinar Harapan.

Tafsir, Ahmad. 2004. Metodologi Pengajaran Agama Islam. Bandung: Remaja Rosdakarya.

Undang-Undang Republik Indonesia Nomor 14 Tahun 2005 Tentang Guru dan Dosen.

Wiriatmadja, Rochiati. 2005. Metode Penelitian Tindakan Kelas. Bandung: Remadja Rosdakarya.

Yasa, Ahmad. 2013. Tafsir Tarbawi (bahan perkuliahan tidak diterbitkan). Bandung: UNINUS. 